\title{
Editorial: Zwanzig Jahre Europäische Rechtsakademie
}

\author{
Wolfgang Heusel
}

(C) ERA 2013

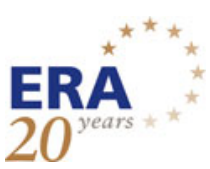

\section{Die ERA - zwanzig Jahre im Dienst des europäischen Rechts}

Am 22. Juni 1992 errichteten das Großherzogtum Luxemburg, das Land RheinlandPfalz, die Stadt Trier und der Verein zur Förderung einer Europäischen Rechtsakademie die Stiftung Europäische Rechtsakademie in Trier. Was wie ein regionales Projekt mit allerdings weitreichenden europäischen Ambitionen aussah, war in Wirklichkeit von Anfang an eine europäische Initiative, hinter der vor allem das Europäische Parlament stand: Es hatte immer wieder die mangelnde Effizienz bei der Umsetzung des Gemeinschaftsrechts in den Mitgliedstaaten beklagt und in wiederholten Entschließungen die Gründung einer Rechtsakademie gefordert, die allen europäischen Rechtspraktikern offenstehen sollte. ${ }^{1}$

Der zwanzigste Jahrestag der Gründung der ERA weist in eine Zeit zurück, in der die europäische Integration nach Jahren der Lethargie wieder große Fahrt aufgenommen hatte. Tatsächlich weist 2012 eine Vielfalt europäischer Gedenktage auf (und dabei gehe ich über die Einführung des Euro-Bargelds vor zehn Jahren hinweg): Ich nenne den 60. Jahrestag der 1952 gestarteten EGKS oder den 40. Jahrestag der ersten Beitrittsverträge überhaupt mit dem Vereinigten Königreich, Irland und Dänemark 1972. Ich erinnere vor allem an das Inkrafttreten der Einheitlichen Europäischen Akte $^{2}$ vor 25 Jahren am 1. Juli 1987. Dieser erste tiefgreifende Reformvertrag der Europäischen Gemeinschaften wurde, nach Jahren der als „Eurosklerose“ be-

\footnotetext{
${ }^{1}$ Zuletzt am 10.9.1991, AB1. C267/33 vom 14.10.1991.

${ }^{2}$ EEA vom 28.2.1986, AB1. L169 vom 29.6.1987.
}

Dr. W. Heusel, Direktor $(\bowtie)$

Europäische Rechtsakademie, Trier, Germany

e-mail:wheusel@era.int 
kannten politischen Stagnation, zur Grundlage des von Jacques Delors angestoßenen Gesetzgebungsprogramms zur Vollendung des Binnenmarktes 1992. Die berühmten 282 Maßnahmen des Delors-Pakets zur Rechtsangleichung ${ }^{3}$ führten jedermann plastisch vor Augen, dass Voraussetzung für eine erfolgreiche Umsetzung und wirksame Anwendung der Binnenmarktgesetzgebung in den Mitgliedstaaten eine nachdrückliche Schulung der nationalen Rechtsanwender in Anwaltschaft, Justiz, Unternehmen und Verwaltung sein würde.

Das Gründungsjahr der ERA 1992 war aber nicht nur das Zieljahr für die Vollendung des Binnenmarktes, es war auch das Jahr der Unterzeichnung des Maastrichter Vertrages ${ }^{4}$, der die Europäische Union und die Grundlage der Währungsunion schuf. 1992 war darüber hinaus das Jahr der Unterzeichnung des heute in den EUMitgliedstaaten weitgehend vergessenen Vertrages von Porto zur Begründung des Europäischen Wirtschaftsraums aus damals zwölf EU-Ländern und sieben EFTAStaaten. $^{5}$

Vor diesem Hintergrund verstehen wir die Gründung der ERA als ein politisches Projekt, das wahrscheinlich nur in dieser historischen Konstellation möglich war: der Acquis wuchs rasant, die rechtliche Integration der Mitgliedstaaten entfaltete erstmals und plötzlich eine von kaum jemandem erwartete Dynamik; die mangelnde Vertrautheit der Juristen mit dem neu entstehenden Recht war mit Händen zu greifen, ihr dringender Fortbildungsbedarf offensichtlich; und bei allen Schwierigkeiten begriffen die Gründer der ERA die Herausforderung vor allem als Chance.

Den Gründern der ERA war schon damals nicht nur die Vermittlung von Rechtswissen oder Verfahrenskenntnissen wichtig. Mindestens genauso bedeutsam erschien ihnen die Begegnung zwischen Juristen verschiedener Berufe und unterschiedlicher Rechtskreise, zwischen verschiedenen juristischen Schulen und all den nationalen Traditionen, die auch heute noch das juristische Selbstverständnis in den Mitgliedstaaten prägen. Mit der Schaffung eines Forums für die innereuropäische Begegnung, für den Erfahrungs- und Gedankenaustausch zwischen Rechtspraktikern aller Mitgliedstaaten haben die Gründer der ERA schon vor 20 Jahren ein Ziel ins Visier genommen, das ungeachtet Walter Hallsteins frühem Diktum von der EG als „Rechtsgemeinschaft“ erst mit dem Amsterdamer Vertrag $1997^{6}$ und der Definition des europäischen Rechts- und Justizraums einen ausdrücklichen primärrechtlichen Bezugspunkt gefunden hat; ein Ziel, das mit dem Stockholmer Programm ${ }^{7}$ und der Mitteilung der Kommission vom 13.9.2011 ${ }^{8}$ zur Justizfortbildung noch immer von höchster Aktualität ist: die Begründung einer gemeinsamen europäischen Rechtskultur, die Schaffung einer europäischen Juristengemeinschaft.

Bereits im November 1991 wurde das Projekt ERA im Kurfürstlichen Palais zu Trier einer großen europäischen Öffentlichkeit präsentiert. Unter der Schirmherr-

\footnotetext{
${ }^{3}$ Weißbuch ,Zur Vollendung des Binnenmarktes“, Juni 1985.

${ }^{4}$ Vertrag von Maastricht vom 7.2.1992, AB1. C191 vom 29.7.1992.

${ }^{5}$ Abkommen über den Europäischen Wirtschaftsraum vom 2.5.1992, AB1. L1/3 vom 3.1.1994.

${ }^{6}$ Vertrag von Amsterdam vom 2.10.1997, AB1. C340 vom 10.11.1997.

${ }^{7}$ AB1. C115/1 vom 4.5.2010.

${ }^{8}$ Mitteilung KOM(2011) 551 endg. vom 13.9.2011: „Förderung des Vertrauens in eine EU-weite Rechtspflege - Eine neue Dimension der justiziellen Aus- und Fortbildung auf europäischer Ebene“.
} 
schaft des Präsidenten des EuGH Ole Due brachte die Veranstaltung über 200 Teilnehmer aus den Mitgliedstaaten und den damaligen Beitrittsländern Finnland, Österreich und Schweden zusammen. Der um die Verwirklichung des Projekts ERA politisch besonders verdiente rheinland-pfälzische Justizminister Peter Caesar definierte das Ziel 1991 wie folgt:

„Wir wünschen uns eine Akademie, bei der sich die europäische Dimension in der Trägerschaft, im Programm, bei den Dozenten, vor allem aber im Teilnehmerkreis widerspiegelt. Geschaffen werden soll eine Weiterbildungseinrichtung für Juristen aus Europa, aus den Organen der Europäischen Gemeinschaften, aus den Mitgliedstaaten, aber auch aus anderen Staaten des sich erweiternden Europa. Ich denke ... hier ... an Ungarn, die Tschechoslowakei, Polen und andere."

Die uns heute so seltsam anmutende Erwähnung der Tschechoslowakei macht deutlich, was seither alles geschehen ist in Europa. Wir gedenken heute der Visionäre und Pioniere von einst, die vor 20 Jahren ein Projekt ins Werk gesetzt haben, dessen Perspektiven zunächst alles andere als gesichert erschienen. Zwar hatte der 1987 ins Amt gekommene Justizminister Caesar die Idee begeistert aufgegriffen und zu einem parteiübergreifend unterstützten Projekt der rheinland-pfälzischen Landesregierung gemacht; doch hing der langfristige Erfolg von der Bereitschaft des Landes ab, die ERA recht bald in eine europäische Trägerschaft mit eigener Handlungsautonomie zu entlassen. Zwar hatte die Gesellschaft für Rechtspolitik bereits im Jahr 1988 unter Federführung des damals in Trier lehrenden jungen Professors Peter-Christian Müller-Graff ein wegweisendes Projektkonzept erstellt; doch konnte niemand ahnen, ob sich ein solches theoretisches Konzept erfolgreich in die Praxis übertragen lassen würde. Zwar bewilligte das Europäische Parlament unter maßgeblicher Beteiligung seines damaligen Trierer Mitgliedes Horst Langes eine großzügige Anschubfinanzierung; aber die langfristige Finanzierung eines auf Dauer zuwendungsabhängigen gemeinnützigen europäischen Instituts war noch keineswegs gewährleistet. Schließlich beteiligte sich zwar der Mitgliedstaat Luxemburg unter Führung seines Premierminister Jacques Santer an der Gründung der ERA; aber auch wenn die EG 1992 nur aus zwölf Mitgliedstaaten bestand, war die förmliche Beteiligung der anderen Mitgliedstaaten an dem neuen Institut alles andere als selbstverständlich.

Heute sind diese uns anfangs plagenden Zweifel und Sorgen soweit ausgeräumt, wie dies nach menschlichen Maßstäben möglich erscheint. Heute ist ,die europäische Dimension in der Trägerschaft" mit 24 europäischen Staaten als Stiftern, beginnend mit Irland im Jahr 2000 bis zu Litauen als jüngstem Stifter, längst Wirklichkeit, und nachdem Belgien 2010 endlich seine Zustiftung angekündigt hat, erwarten wir in Kürze den Beitritt Lettlands. „Im Programm, bei den Dozenten ... [und] im Teilnehmerkreis" hat sich der europäische Charakter der ERA von Anfang an widergespiegelt. Gemeinsam mit den anderen Stiftern hat Rheinland-Pfalz der ERA mit einem revidierten Statut bereits im Jahr 2000 die für ihre Entwicklung unverzichtbare Handlungsfreiheit zugestanden. Die Betriebskosten der Akademie werden seit zwanzig Jahren nicht nur vom Land Rheinland-Pfalz, sondern zu einem sehr erheblichen Teil von der EU bezuschusst. Hierfür sage ich meinen herzlichen Dank Landtag und Landesregierung sowie dem Europäischen Parlament und der Europäischen Kommission. 
Die Pionierzeit liegt weit zurück, und neue Herausforderungen prägen unsere aktuelle und künftige Strategie. Vor fünf Jahren habe ich an gleicher Stelle ein ehrgeiziges Projekt zum Ausbau der personellen und räumlichen Kapazität der ERA angekündigt, das wir inzwischen gemeinsam mit unseren Stiftern und mit Hilfe der Europäischen Union umsetzen konnten. Die beiden Säulen unserer 2007 beschlossenen Ausbaustrategie sind heute sozusagen mit Händen zu greifen: Zum einen haben wir unseren Mitarbeiterstab vergrößern, einen vierten Fachbereich eröffnen und seit dem Jahr 2011 unser Programmangebot deutlich erweitern können. Zum andern haben wir im gleichen Jahr unser neues Dienstgebäude in Betrieb genommen, das uns vielfach genutzte verbesserte und erweiterte Tagungs- und Arbeitsbedingungen bietet. Ich möchte nicht versäumen, hier noch einmal all denjenigen Stiftern meine Reverenz zu erweisen, die durch zum Teil sehr beträchtliche finanzielle Beiträge den Erwerb und Umbau des neuen Gebäudes ermöglicht haben: dem Bund (Bundesregierung und Bundestag), wiederum dem Land Rheinland-Pfalz, dem Großherzogtum Luxemburg, Irland, Portugal (dem Centro de Estudos Judiciários), Bulgarien, der Slowakei und Malta sowie Thüringen und dem Saarland.

\section{Jubiläumskongress: Die Bürger im Herzen des europäischen Rechts}

Zur Feier des zwanzigsten Jahrestages ihrer Gründung veranstaltete die ERA vom 18.-20. Oktober 2012 in Trier einen Jubiläumskongress, in dessen Mittelpunkt der Bürger stand - der Bürger als Grundrechtsträger und Inhaber politischer Rechte, der Bürger als Subjekt und Objekt justizförmlicher Verfahren, und der Bürger als Träger sozialer Rechte im Europäischen Binnenmarkt. Glanzlicht des Kongresses war eine Ansprache der Vizepräsidentin der Europäischen Kommission und Justizkommissarin Viviane Reding, die unter anderem das Rechtsstaatsprinzip als Grundpfeiler des europäischen Justizraums hervorhob.

Das vorliegende Heft des ERA Forum enthält neben den Festansprachen der Vizepräsidentin Bulgariens Margarita Popova sowie der Präsidentin des Obersten Gerichts Finnlands und des Kuratoriums der ERA Pauliine Koskelo ausgewählte Fachbeiträge zu den unterschiedlichen Kongressthemen. Zu Beginn arbeitet der von Claus-Dieter Ehlermann erstattete Eröffnungsvortrag heraus, welchen Gewinn der Unionsbürger aus zwanzig Jahren Maastrichter Vertrag ziehen kann. Dieser Beitrag leitet über zur Wiedergabe einer prominent besetzten Podiumsdiskussion, die unter Vorsitz des Direktors des Europa-Instituts der Universität des Saarlandes Torsten Stein die Legitimitätsanforderungen an den Souveränitätsübergang von den nationalen Verfassungen auf die europäische Ebene erörtert. Teilnehmer waren Lady Justice Arden, Lady Justice des englischen Court of Appeal; der ehemalige Vizepräsident des Bundesverfassungsgerichts Winfried Hassemer; der Präsident des Europäischen Gerichtshofs Vassilios Skouris; und der Richter des polnischen Verfassungsgerichts Andrzej Wróbel. Von Professor Wróbel stammt auch der nachstehend abgedruckte Beitrag „Die Grenzen der europäischen Integration im Lichte jüngerer Entscheidungen des polnischen Verfassungsgerichts“. Den Bogen zu diesem Thema schlägt der Beitrag der Rechtskorrespondentin der Irish Times Carol Coulter zur Rolle der Medien im europäischen Integrationsprozess, mit dem der Jubiläumskongress endete. 
Aus den Sitzungen der Fachgruppen bringt das vorliegende Heft drei Beiträge. Der frühere Rechtsberater des Europäischen Parlaments Gregorio Garzón Clariana stellt die Entwicklung der politischen Teilhaberechte der Unionsbürger in den letzten zwanzig Jahren dar. Vom Vizepräsidenten des Europäischen Gerichtshofs Koen Lenaerts, dessen neugeschaffenes Amt kurz zuvor erstmals besetzt worden war, stammt der Beitrag zum Konzept der Unionsbürgerschaft in der Rechtsprechung des Gerichtshofs. Der Präsident der Queen's Bench Division des High Court of England and Wales Sir John Thomas schließlich stellt die Frage nach Erfolg oder Fehlschlag des Prinzips der gegenseitigen Anerkennung in der strafrichterlichen Praxis.

Der Kongress wurde mit Unterstützung eines Vorbereitungskomitee aus dem Kreis des Kuratoriums der ERA vorbereitet, dessen Mitgliedern ich für ihre Unterstützung herzlich danke: Josef Azizi, Mitglied des Gerichts der EU; Gregorio Garzón Clariana, ehemaligem Rechtsberater des Europäischen Parlaments; den Rechtsanwälten Hans-Jürgen Hellwig und Péter Köves, ehemaligen Präsidenten des CCBE; Catherine Kessedjian, Professorin an der Universität Paris-II Panthéon-Assas; Pauliine Koskelo, Präsidentin des finnischen Obersten Gerichtshofes; und Peter-Christian Müller-Graff, Professor an der Universität Heidelberg. Zu den Mitgliedern des Vorbereitungskomitees gehörte auch der verstorbene Ehrenvorsitzende unseres Kuratoriums John Toul$\min$.

\section{In memoriam John Toulmin}

Dieses Heft mit Beiträgen zum zwanzigjährigen Jubiläum der Europäischen Rechtsakademie ist der geeignete Ort, zuletzt John Toulmins zu gedenken, der von 1993 bis 2012 fast zwanzig Jahre lang Mitglied des Kuratoriums der ERA und von 1997 bis 2010 vierzehn Jahre dessen Präsident war. In Würdigung seines langjährigen Engagements veröffentlichte die Akademie als Sonderheft des ERA Forum 2011 die Festschrift A European Law Practitioner - Liber amicorum John Toulmin. Am 14. Februar 2011 wurde John Toulmin als Richter des Technology and Construction Court von Lord Chief Justice Lord Judge in einer feierlichen Zeremonie in den Ruhestand verabschiedet. Noch vor seinem Tod am 2. Juli 2012 schloss er die Veröffentlichung seines Buches Expanding the Horizons ${ }^{9}$ ab, in dem Beiträge aus sehr unterschiedlichen Tätigkeitsfeldern seines Berufslebens einschließlich seines Engagements für die ERA versammelt sind. Am 5. November 2012 fand in der Kirche der Tempelritter in London, die den englischen Rechtsberufen besonders verbunden ist, ein Gedenkgottesdienst für John Toulmin statt, in dessen Rahmen der Verfasser die Ehre hatte, im Namen der Europäischen Rechtsakademie folgenden Dank zu sagen:

As an outstanding lawyer, an eminent educator and a genuine European, John Toulmin not only "expanded the horizons" of what at times might have appeared as a rather inward-looking legal profession. We've just heard that he also "built bridges" between the Bars and Law Societies of Europe and world-wide.

\footnotetext{
9“"Expanding the Horizons - On Active Service in Law and Education", Wildy, Simmonds and Hill Publishing, London 2012.
} 
But he did more: He was instrumental in constructing the institution which I have the honour to represent here, the Academy of European Law, ERA. "Expanding the Horizons - Building Bridges - and Devising the construction of a new Institution" seems a fitting summary of some of the major achievements of a judge of the Technology and Construction Court.

In 1992, the year when ERA's charter as a public charity foundation was signed and put into effect, John was First Vice President of the CCBE. The following year, on 5 July 1993 and then as CCBE President, John came to Trier for the first time on official mission to attend the first meeting of ERA's advisory board which, quite untechnically, was labelled "Board of Trustees". John's open mind and active interest in European politics and legal policy made him an instantaneous supporter of what at the time was no more than a fledgling project - albeit a project with a promising potential, the project to build a European institute with the mission to familiarise legal professionals throughout Europe with European law, to make them aware of its relevance for their every-day work; and to create an accessible, hospitable and neutral framework for them to meet, to exchange and to build trust: so that they could find out what they have in common, that beyond all the striking contrasts and differences on the surface of our legal and judicial orders there is a common core of values, a common set of principles and a common sense for justice which make up our European identity. John represented all of that. The need to raise and preserve this awareness seems no less pressing nowadays than it was twenty years ago, as John very rightly emphasised in his Lent Reading as Master Reader at Middle Temple Hall in 2008; and I have learned from him that preserving and defending our common values and achievements can indeed constitute a conservative virtue.

In the smaller world of our institute, John played a central role as active supporter and great friend from the first meeting of the Trustees in 1993, and in fact did not miss a single of the subsequent meetings until May this year when his state of health, very much to his regret, for the first time did not allow him to come. In 1997, still during ERA's pioneer age, John was elected President of the Trustees, an office to which he was re-elected three times and which he filled for 14 exciting years until 2011. In 1998 his role even became vital for the survival of ERA, when we had to fight for our independence, which John did with the power of his argument and the strength of his conviction. This eventually led to the adoption of a new statute for the foundation in 2000, which guarantees the Institute's autonomy for as long as we are prepared to defend it.

John never tired of aiming at new strategic horizons, as for him consolidation rather meant retreat. In his inspired contribution to Richard O'Havery's voluminous "History of the Middle Temple" (Hart 2011) John concludes his chapter on "The Temple Church" with the statement that "any institution needs regular renewals of the spirit, otherwise it will die” (p. 30). This fundamental truth guided him and us in building and developing ERA in the past twenty years. It will remain John's legacy in ERA as in other institutions which enjoyed the privilege of his affection. 